\title{
Histamine up-regulates fibroblast growth factor receptor 1 and increases FOXP2 neurons in cultured neural precursors by histamine type 1 receptor activation: conceivable role of histamine in neurogenesis during cortical development in vivo
}

Anayansi Molina-Hernández ${ }^{1,2}$, Griselda Rodríguez-Martínez ${ }^{1 \dagger}$, Itzel Escobedo-Ávila ${ }^{1 \dagger}$ and Iván Velasco ${ }^{1 *}$

\begin{abstract}
Background: During rat development, histamine $(\mathrm{HA})$ is one of the first neuroactive molecules to appear in the brain, reaching its maximal value at embryonic day 14 , a period when neurogenesis of deep layers is occurring in the cerebral cortex, suggesting a role of this amine in neuronal specification. We previously reported, using highdensity cerebrocortical neural precursor cultures, that micromolar HA enhanced the effect of fibroblast growth factor (FGF)-2 on proliferation, and that HA increased neuronal differentiation, due to HA type 1 receptor $\left(H_{1} R\right)$ activation.
\end{abstract}

Results: Clonal experiments performed here showed that HA decreased colony size and caused a significant increase in the percentage of clones containing mature neurons through $\mathrm{H}_{1} \mathrm{R}$ stimulation. In proliferating precursors, we studied whether HA activates G protein-coupled receptors linked to intracellular calcium increases. Neural cells presented an increase in cytoplasmic calcium even in the absence of extracellular calcium, a response mediated by $H_{1} R$. Since FGF receptors (FGFRs) are known to be key players in cell proliferation and differentiation, we determined whether HA modifies the expression of FGFRs1-4 by using RT-PCR. An important transcriptional increase in FGFR1 was elicited after $\mathrm{H}_{1} \mathrm{R}$ activation. We also tested whether HA promotes differentiation specifically to neurons with molecular markers of different cortical layers by immunocytochemistry. HA caused significant increases in cells expressing the deep layer neuronal marker FOXP2; this induction of FOXP2-positive neurons elicited by $\mathrm{HA}$ was blocked by the $\mathrm{H}_{1} \mathrm{R}$ antagonist chlorpheniramine in vitro. Finally, we found a notable decrease in FOXP2+ cortical neurons in vivo, when chlorpheniramine was infused in the cerebral ventricles through intrauterine injection.

Conclusion: These results show that $\mathrm{HA}$, by activating $\mathrm{H}_{1} \mathrm{R}$, has a neurogenic effect in clonal conditions and suggest that intracellular calcium elevation and transcriptional up-regulation of FGFR1 participate in HA-induced neuronal differentiation to FOXP2 cells in vitro; furthermore, $\mathrm{H}_{1} \mathrm{R}$ blockade in vivo resulted in decreased cortical FOXP2+ neurons.

Keywords: Neural stem cells, $\mathrm{H}_{1} \mathrm{R}$, Clonal analysis, FGF receptors, Cerebral cortex, FOXP2

\footnotetext{
* Correspondence: ivelasco@ifc.unam.mx

${ }^{\dagger}$ Equal contributors

'Instituto de Fisiología Celular - Neurociencias, Universidad Nacional

Autónoma de México, México, D.F. 04510, México

Full list of author information is available at the end of the article
} 


\section{Background}

The mammalian neocortex comprises six layers, each containing neurons with its own morphology, functional properties and connections as well as time of origin. Neocortex formation during development is generated in an inside-out pattern, with the oldest neurons (layer VI) closest and the youngest neurons (layers II/III) farthest from their birthplace near the ventricle [1-4]. The region where migration stops is defined by a layer of specialized pioneer neurons called Cajal-Retzius cells, which migrate tangentially early during development [5].

After development, the deepest layers of cortical neurons (layers V and VI) contain neurons that interconnect areas of the cortex or projection neurons reaching subcortical structures. Layer IV is the layer where most extracortical inputs arrive, particularly from the sensory thalamus, whereas the superficial layers are composed mainly of local circuits that form reciprocal connections with the deep layers [6]. Neurons within the cortex are born in a precise timing and this is essential for generating the final complex laminar cytoarchitecture, in which it is possible to identify specific layer markers such as reelin and p73 (layer I), stab2 and Cux1 (layers II/III and IV), Tbr1, CTIP2, Sox5, Tle4, FOXP2, ER81, OTX1 and Stab2 (layers V and VIa) and, finally, Tbr1 and CTIP2 for layer VIb $[7,8]$.

During rat development, histamine (HA) is one of the first neuroactive molecules to be detected in the central nervous system (CNS), being present as early as embryonic day (E)12 and reaching its maximum value at E14 to E16 in the prosencephalic area [9], a five-fold higher value relative to adult brain levels. Between E14 and E18, fibers from the transient histaminergic neurons can be detected in the mesencephalon, passing through the ventral tegmental area and within the medial forebrain bundle and the optic tract, to reach the frontal and the parietal cortices at E15, earlier than other monoaminergic systems [9-13]; this coincides with the period in which neuronal differentiation is occurring in the cerebral cortex [14]. This rise in HA, together with mRNA expression for $\mathrm{HA}$ receptors type $1\left(\mathrm{H}_{1} \mathrm{R}\right)$ and type 2 $\left(\mathrm{H}_{2} \mathrm{R}\right)$ in the developing CNS suggests a role of HA during brain development [15].

The in vitro effects of HA on proliferation and neuronal differentiation of cerebral cortex neural precursor cells (NPC) were studied by our group. We showed that $100 \mu \mathrm{M}$ HA increases cell proliferation mainly through $\mathrm{H}_{2} \mathrm{R}$ activation without causing premature differentiation in the presence of fibroblast growth factor (FGF)-2 [16]. We have recently reported that $\mathrm{HA}$ is required in the proliferative phase (+FGF-2) of NPC to induce neurogenesis [17]. After FGF-2 withdrawal, HA augmented neuronal differentiation by $\mathrm{H}_{1} \mathrm{R}$ stimulation [16]. $\mathrm{H}_{1} \mathrm{R}$ is a $G$ protein-coupled receptor, which after activation produces inositol triphosphate $\left(\mathrm{IP}_{3}\right)$ and diacylglycerol, that in turn promote an increase in $\left[\mathrm{Ca}^{2+}\right]_{\mathrm{i}}$ due to activation of $\mathrm{IP}_{3}$ receptors in the endoplasmic reticulum, and the activation of protein kinase $C$ [18]. Calcium release from intracellular stores into the cytosol is a critical component during ontogenesis and contributes particularly to the formation and maintenance of dendritic structures $[19,20]$.

In this report we studied whether HA-induced neurogenesis was present at the single-cell level by clonal analysis. In proliferating NPC, HA induced calcium elevations mediated by $\mathrm{H}_{1} \mathrm{R}$ activation. FGF receptors (FGFRs) transcripts were up-regulated by $\mathrm{HA}$ in the presence of FGF-2, with FGFR1 presenting a sustained elevation after two hours. Cultured NPC readily differentiated to neurons that express the deep cortical layers marker FOXP2 after HA treatment. Antagonism of $\mathrm{H}_{1} \mathrm{R}$ in vivo during cortical development resulted in decreased immuno-reactivity to $\beta$-tubulin III and FOXP2.

\section{Results}

We have previously reported that NPC, before and after differentiation, express $\mathrm{H}_{1} \mathrm{R}$ and $\mathrm{H}_{2} \mathrm{R}$ mRNA (by RT$\mathrm{PCR}$ ) and their corresponding proteins (by immunoblot). We analyzed $\mathrm{H}_{1} \mathrm{R}$ and $\mathrm{H}_{2} \mathrm{R}$ expression and its regulation by HA at the cellular level, using specific antibodies for these histaminergic receptors. Additional file 1 shows that $\mathrm{H}_{1} \mathrm{R}$ and $\mathrm{H}_{2} \mathrm{R}$ are present in $81 \pm 1.8 \%$ and $92 \pm$ $2.0 \%$ of passage (P) 2 proliferating NPC, respectively. Cultures treated with $100 \mu \mathrm{M}$ HA for 4 days showed very similar proportions of $\mathrm{H}_{1} \mathrm{R}-(83 \pm 1.0 \%)$ and $\mathrm{H}_{2} \mathrm{R}$ positive cells $(94 \pm 1.4 \%)$.

\section{Neuronal differentiation is promoted by histamine in clonally-derived colonies}

$\mathrm{HA}$ increases the proportion of differentiated neurons in cortical NPC cultures, an effect mediated by $\mathrm{H}_{1} \mathrm{R}$ activation [16]. We performed experiments at clonal density, in which HA was present all along proliferation and differentiation phases, to establish if this neurogenic effect was also present in colonies arising from a single cell. Isolated individual cells were identified and allowed to proliferate in the presence of FGF-2 for eight days, followed by FGF withdrawal for six additional days to induce differentiation. Since we observed apparent changes in the size of colonies between the control and HA condition, we measured the area and total cell numbers per clonal colony after crystal violet staining (Figures 1A-D). HA caused a significant $26 \%$ decrease in colony area (Figure 1E) and also a 16\% non-significant reduction in cell number (Figure 1F). Co-incubation of HA with the $\mathrm{H}_{1} \mathrm{R}$ antagonist chlorpheniramine caused a significant increase in both colony area and cell number, relative to control and also to $100 \mu \mathrm{M}$ HA. Incubation of HA with 


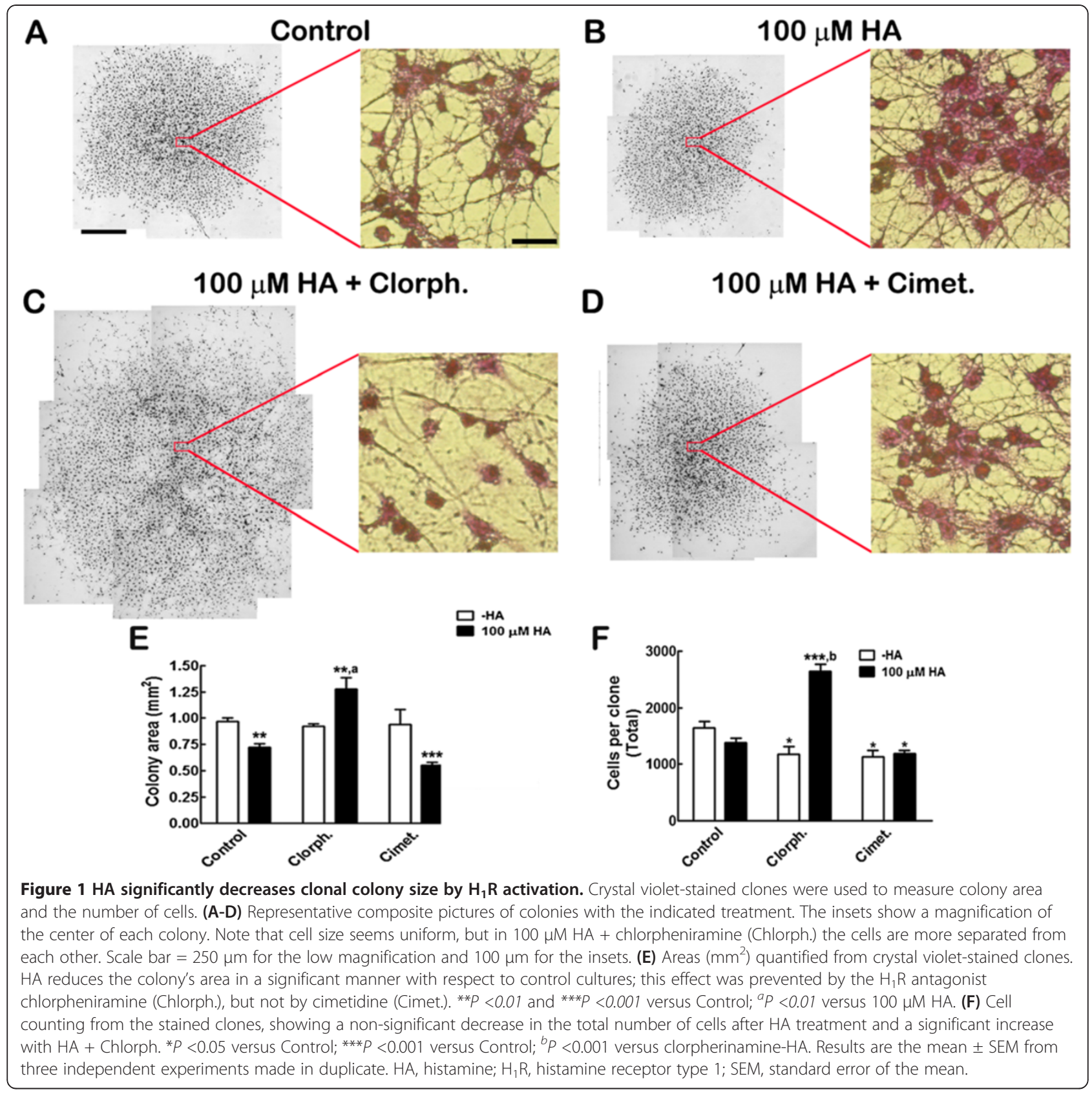

the $\mathrm{H}_{2} \mathrm{R}$ antagonist cimetidine produced colonies significantly smaller than controls; cell number per colony was also significantly decreased by cimetidine, regardless of HA presence, relative to the control value.

We next analyzed cell fate in these clonal colonies. Mature neurons (MAP2+) and astrocytes (GFAP+) were detected by immunofluorescence to score the proportion of colonies that contained mature neurons. HA increased 2.8-fold the number of colonies with neurons after differentiation (Figure 2); the HA effect was completely prevented when cultures were co-treated with chlorpheniramine, but was insensitive to cimetidine, since no significant difference was found between HA and $\mathrm{HA}+$ cimetidine conditions. Cultures treated with the $\mathrm{H}_{1} \mathrm{R}$ or the $\mathrm{H}_{2} \mathrm{R}$ antagonist without $\mathrm{HA}$, did not show significant changes. Concerning astrocytic differentiation, GFAP+ cells were detected in all clonal colonies.

Histamine causes an increase of intracellular calcium dependent on activation of $\mathrm{H}_{1} \mathrm{R}$ in undifferentiated cells To establish if addition of HA to NPC elicited increases in $\left[\mathrm{Ca}^{2+}\right]_{\mathrm{i}}$, P2 NPC growing with FGF-2 were loaded with the ratiometric calcium probe Fura- 2 and re-plated in glass-bottom dishes for imaging. The intracellular 


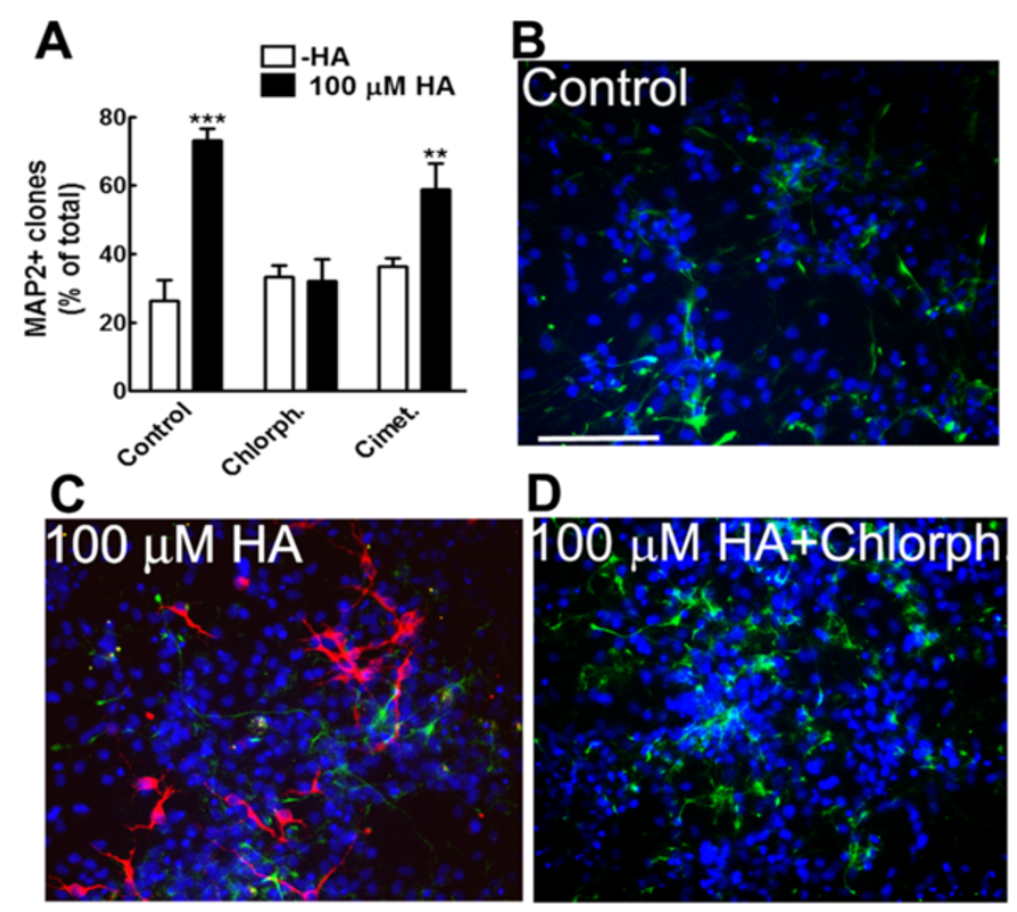

Figure $2 \mathrm{HA}$ activates $\mathrm{H}_{1} \mathrm{R}$ to increase the number of clones with differentiated neurons. (A) Significant increase in the number of colonies with microtubule associated protein 2 (MAP2) + neurons promoted by HA and its prevention by chlorpheniramine (Chlorph.) ${ }^{* *} P<0.01$ and ${ }^{* *} P$ $<0.001$ versus Control. (B-D) Representative micrographs of clonal colonies after immunocytochemical detection of mature neurons (MAP2+; red), astrocytes (GFAP+; green) and nuclei (blue) in Control (B), HA-treated (C) and HA + chlorpheniramine (Chlorph.)-treated (D) cells are shown. Scale bar $=100 \mu \mathrm{m}$. GFAP, glial fibrillary acidic protein; HA, histamine; $\mathrm{H}_{1} \mathrm{R}$, histamine receptor type 1 .

calcium concentration is related to the ratio (R) of emission at $510 \mathrm{~nm}$, resulting from alternating excitation of Fura- 2 between $340 \mathrm{~nm}$ and $380 \mathrm{~nm}\left(\mathrm{R}=\mathrm{F}_{340} / \mathrm{F}_{380}\right)$. We found that $65 \%$ of cells increased on average 2.2 -fold the basal $\left[\mathrm{Ca}^{2+}\right]_{\mathrm{i}}$ in response to $\mathrm{HA}$ addition (Figure $3 \mathrm{~A}$ ). Such HA-elicited rise was completely blocked by coincubation with chlorpheniramine (Figure 3B); cimetidine did not prevent the $\left[\mathrm{Ca}^{2+}\right]_{\mathrm{i}}$ increase produced by HA (Figure 3D). Antagonists added before HA did not modify the basal levels of $\left[\mathrm{Ca}^{2+}\right]_{\mathrm{i}}$ (Figures $3 \mathrm{~B}$ and D). When experiments were done in the absence of extracellular $\mathrm{Ca}^{2+}$, we found a small but significant 1.3 -fold increase in the fluorescence ratio stimulated by HA, caused by release of $\mathrm{Ca}^{2+}$ from intracellular deposits (Figure 3C). These results show that NPC express functional $\mathrm{H}_{1} \mathrm{R}$, which after activation elicit a $\left[\mathrm{Ca}^{2+}\right]_{\mathrm{i}}$ increase.

\section{Histamine up-regulates transcripts for FGF receptors during proliferation}

In addition to calcium signaling, regulation of FGFRs might contribute to HA effects in neuronal commitment. We therefore analyzed the expression of FGFRs in proliferating NPC. In these experiments, cells were stimulated with $\mathrm{HA}$ and/or histaminergic drugs, and RNA was extracted at different time points $(30,60$ or $120 \mathrm{mi}$ nutes after treatment), followed by retrotranscription and endpoint PCR amplification with specific primers to detect FGFR1, FGFR2 (isoforms IIIB and IIIC), FGFR3 and FGFR4 expression. We were able to detect all listed FGFRs, except FGFR2-IIIB in control conditions. HA caused a transcriptional up-regulation of FGFR1, FGFR2IIIC and FGFR3 in samples stimulated for 30 minutes. The expression of FGFR1 and FGFR2-IIIC showed a biphasic increase, while mRNA levels for FGFR3 showed a progressive decline after 60 to 120 minutes (Figures 4A, $4 \mathrm{D}$ and $4 \mathrm{G})$.

The significant increase in mRNA for FGFR1 was 5.5 times relative to control after 2 hours of HA addition. FGFR1 up-regulation analyzed 30 minutes after HA stimulation, was sensitive to $1 \mu \mathrm{M}$ chlorpheniramine, but not to $30 \mu \mathrm{M}$ cimetidine, with neither antagonist having an effect on its own (Figures $4 \mathrm{~B}$ and $4 \mathrm{C}$ ). On the other hand, the HA-induced increase in FGFR2-IIIC mRNA showed a different pharmacology: at 30 minutes, neither antagonist had an effect, but after stimulation for 120 minutes, $\mathrm{H}_{1} \mathrm{R}$ or $\mathrm{H}_{2} \mathrm{R}$ antagonists were able to decrease FGFR2-IIIC expression to control levels (Figures 4E and 4F). FGFR3 expression was stimulated by HA treatment for 30 minutes; however, mRNA levels for this FGFR showed a progressive non-significant decline relative to control levels after 60 and 120 minutes (Figure 4G). At 30 minutes, the HA-elicited increase was neither prevented 


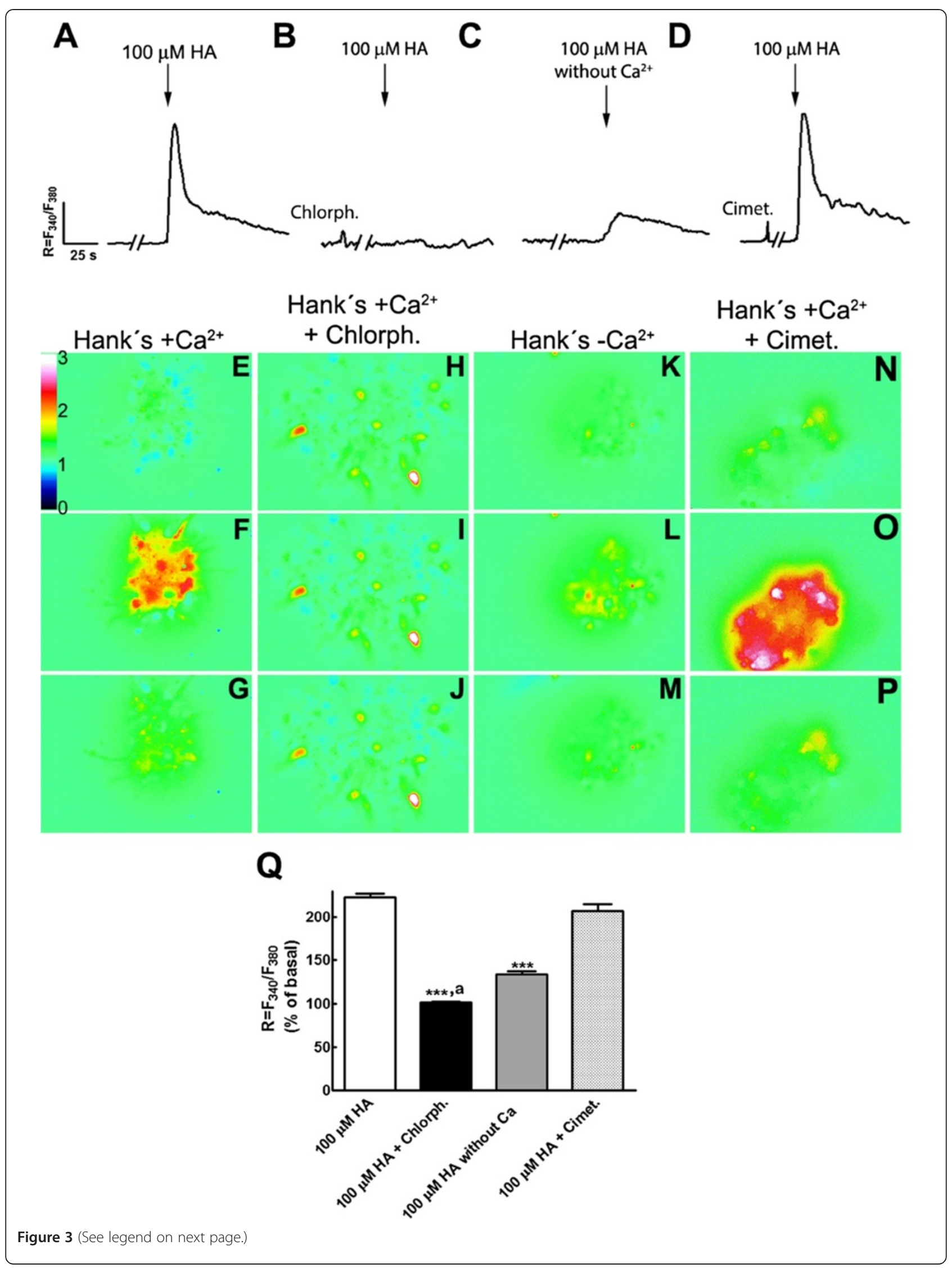


(See figure on previous page.)

Figure 3 Increase of intracellular calcium induced by $\mathbf{H A}$ through activation of $\mathbf{H}_{\mathbf{1}} \mathbf{R}$. (A-D) Representative trace from responsive NPC to 100 $\mu \mathrm{M} \mathrm{HA}$, showing the average ratio $(R)$ of fluorescence of Fura-2 alternating excitation between $340 \mathrm{~nm}\left(F_{340}\right)$ and $380 \mathrm{~nm}\left(F_{380}\right)$ as a measure of $\left[\mathrm{Ca}^{2+}\right]_{\mathrm{i}}$. HA addition elicited a clear increase (A) that was blocked by co-incubation of HA with the $\mathrm{H}_{1} \mathrm{R}$ antagonist chlorpheniramine (Chlorph.) (B), (C) HA added in a medium without extracellular calcium caused a discrete $\left[\mathrm{Ca}^{2+}\right]_{\mathrm{i}}$ rise. (D) Cimetidine (Cimet.) did not block the $\mathrm{Ca}^{2+}$ elevation caused by HA. Note that neither chlorpheniramine nor cimetidine modified basal $\mathrm{Ca}^{2+}$ levels. (E-P) Representative images from the same experiment in $\mathbf{A}$ to $\mathbf{D}$ at different times: before the stimulus $(\mathbf{E}, \mathbf{H}, \mathbf{K}, \mathbf{N})$, after $\mathbf{H A}$ addition $(\mathbf{F}, \mathbf{I}, \mathbf{L}, \mathbf{O})$ and 80 seconds after the stimulus was given $(\mathbf{G}, \mathbf{J}, \mathbf{M}, \mathbf{P})$. Chlorpheniramine and cimetidine were incubated during the five minutes prior to HA addition. The bar on the side of image $\mathbf{E}$ indicates the scale for $R=F_{340} / F_{380}$. (Q) Average values of ratiometric Fura-2 measurements, expressed as a percentage of the basal (before stimulus) value are presented in the graph as the mean \pm standard error from three to five independent experiments. ${ }^{* * *} P<0.0001$ versus $100 \mu \mathrm{M} \mathrm{HA}$ and also versus $100 \mu \mathrm{M} \mathrm{HA}+$ Cimet.; $^{a} P<0.01$ versus $100 \mu \mathrm{M} \mathrm{HA}$ without extracellular $\mathrm{Ca}^{2+}$. HA, histamine; $\mathrm{H}_{1} \mathrm{R}$, histamine receptor type 1; NPC, neural precursor cells.

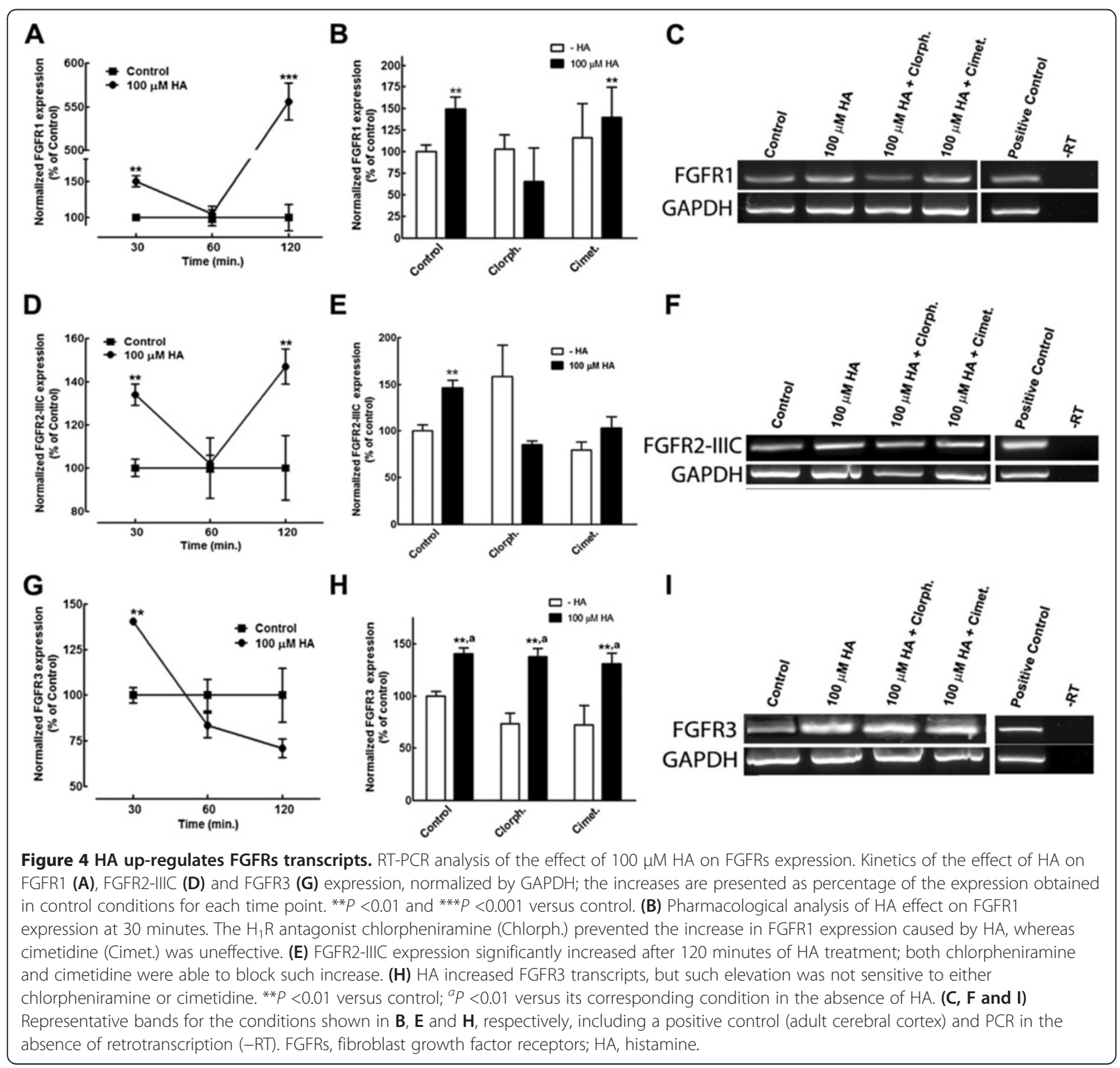


by chlorpheniramine nor by cimetidine (Figures 4H and 4I). Although we observed FGFR4 expression in control conditions, $100 \mu \mathrm{M} \mathrm{HA}$, alone or in combination with $\mathrm{H}_{1} \mathrm{R}$ or $\mathrm{H}_{2} \mathrm{R}$ antagonists, did not significantly change such levels at the studied time points (data not shown).

\section{Histamine increases FOXP2 neurons after differentiation of cultured NPC}

In order to investigate if HA selectively induces specific neuronal phenotypes, we performed immunocytochemical detection of some markers characteristic of specific cortical layers after six days of differentiation. We used the following laminar markers (Figure 5A): p73 (CajalRetzius neurons), reelin (Cajal-Retzius neurons and subplate neurons), calretinin (Cajal-Retzius and subplate neurons), CUX1 (upper layer neurons) and FOXP2 (deeper layer neurons), together with the mature neuronal protein MAP2. As previously reported by our group, $100 \mu \mathrm{M}$ HA caused a 2.7fold increase in the number of MAP2+ cells (Figure 5B). We did not find, in control nor in HA-treated cultures, Cajal-Retzius neurons, since we did not observed any p73+ cells, although there were calretinin + and reelin+ cells; such cells positive for calretinin and reelin might correspond to subplate neurons. Particularly the calretinin+ population was significantly increased (1.6-fold) in HA-treated cultures when quantified as cells expressing this marker relative to the total cell number (Figure 5B). However, given that the number of neurons also increased significantly after HA addition, we calculated the percentage of MAP2+ cells that also express calretinin. Surprisingly, HA caused a significant decrease in the proportion of calretinin+ neurons (Figure 5C). The molecular marker for the upper layer neurons CUX1 was not detected in control cultures, but CUX1+ cells were present in cultures treated with HA, although at a low proportion and with none of them coexpressing MAP2. HA did not affect the percentage of gamma-aminobutyric acid (GABA)+ cells after differentiation; these GABA-positive cells might be immature neurons, since they do not express MAP2.

A significant 1.5-fold increase was observed in the number of cells expressing the deep layer marker FOXP2 after HA addition, when quantified as the percent of total cells. This significant increase is also present when we analyzed the proportion of FOXP2+ cells that express MAP2 (Figure $5 \mathrm{C}$ ), thus resulting in more neurons and a higher percentage of neurons that express FOXP2 after HA treatment.

\section{$\mathrm{H}_{1} \mathrm{R}$ antagonism prevents the induction of FOXP2 neuronal phenotype by histamine in cultured NPC and decreases the number of FOXP2 neurons in the cortical neuroepithelium in vivo}

To investigate if the increase in the proportion of FOXP2+/MAP2+ cells caused by $\mathrm{HA}$ was sensitive to the $\mathrm{H}_{1} \mathrm{R}$ antagonism, we performed experiments in which co-incubation of $\mathrm{HA}$ and chlorpheniramine was made. This resulted in abolition of FOXP2 induction, with the antagonist alone having no effect relative to control conditions (Figures 6A to 6E). To study if activation of $\mathrm{H}_{1} \mathrm{R}$ might play a role during cortical development in vivo, we set up a system for intrauterine injection of E12 embryos in the lateral ventricles. Two days later, the dam was euthanized and the developing embryos recovered and analyzed by immunohistochemistry. In vehicle-injected animals, we found neurons expressing $\beta$-tubulin III that were also positive for FOXP2 (Figures 6F and 6G). However, after injection of $25 \mu \mathrm{g}$ of chlorpheniramine, there was an apparent decrease in both $\beta$-tubulin III and FOXP2+ cells (Figure 6H), without obvious alterations in the cortical area. This effect seems to be specific for the developing cortex, because embryos that received the same amount of chlorpheniramine did not suffer a decrease in $\beta$-tubulin III staining in the midbrain (Escobedo-Ávila et al., unpublished observations).

\section{Discussion}

NPC are useful to study the role of a number of factors affecting self-renewal, proliferation and cell fate in vitro and also can guide researchers on the compounds to be tested in vivo. We have previously reported, using cortical NPC, that HA increases cell division during the proliferative phase, in the presence of FGF-2, mainly through $\mathrm{H}_{2} \mathrm{R}$ activation without affecting the high proportion of Nestin-positive cells, a marker used for neural stem and precursor cells; after differentiation, this amine increases the proportion of neurons by $\mathrm{H}_{1} \mathrm{R}$ activation [16]. In this work, we show that: (i) $\mathrm{HA}$, through $\mathrm{H}_{1} \mathrm{R}$ stimulation, decreases the area of clonal colonies and increases the proportion of colonies containing mature neurons after differentiation of NPC; (ii) HA promotes an increase in $\left[\mathrm{Ca}^{2+}\right]_{\mathrm{i}}$ by $\mathrm{H}_{1} \mathrm{R}$ activation in proliferating neural cells; (iii) HA receptor activation up-regulates FGFR1 and FGFR2-IIIC expression during proliferation; (iv) HA promotes differentiation of cultured NPC into FOXP2-positive neurons by $\mathrm{H}_{1} \mathrm{R}$ stimulation; and (v) blockade of $\mathrm{H}_{1} \mathrm{R}$ in vivo results in decreased numbers of FOXP2 neurons in the developing rat cerebral cortex.

To test if HA was able to induce neuronal commitment at the single cell level, we performed clonal analysis, the most stringent assay to test for differentiation potential in vitro. Whereas HA treatment produced a noticeable decrease in the size of colonies, incubation of $\mathrm{HA}+$ chlorpheniramine significantly increased the area of the colonies in relation to control and HA-treated cells. Cimetidine, on the other hand, did not antagonize HA action (Figure 1E). To investigate if these changes in colony area were related to variations in the total cell numbers 


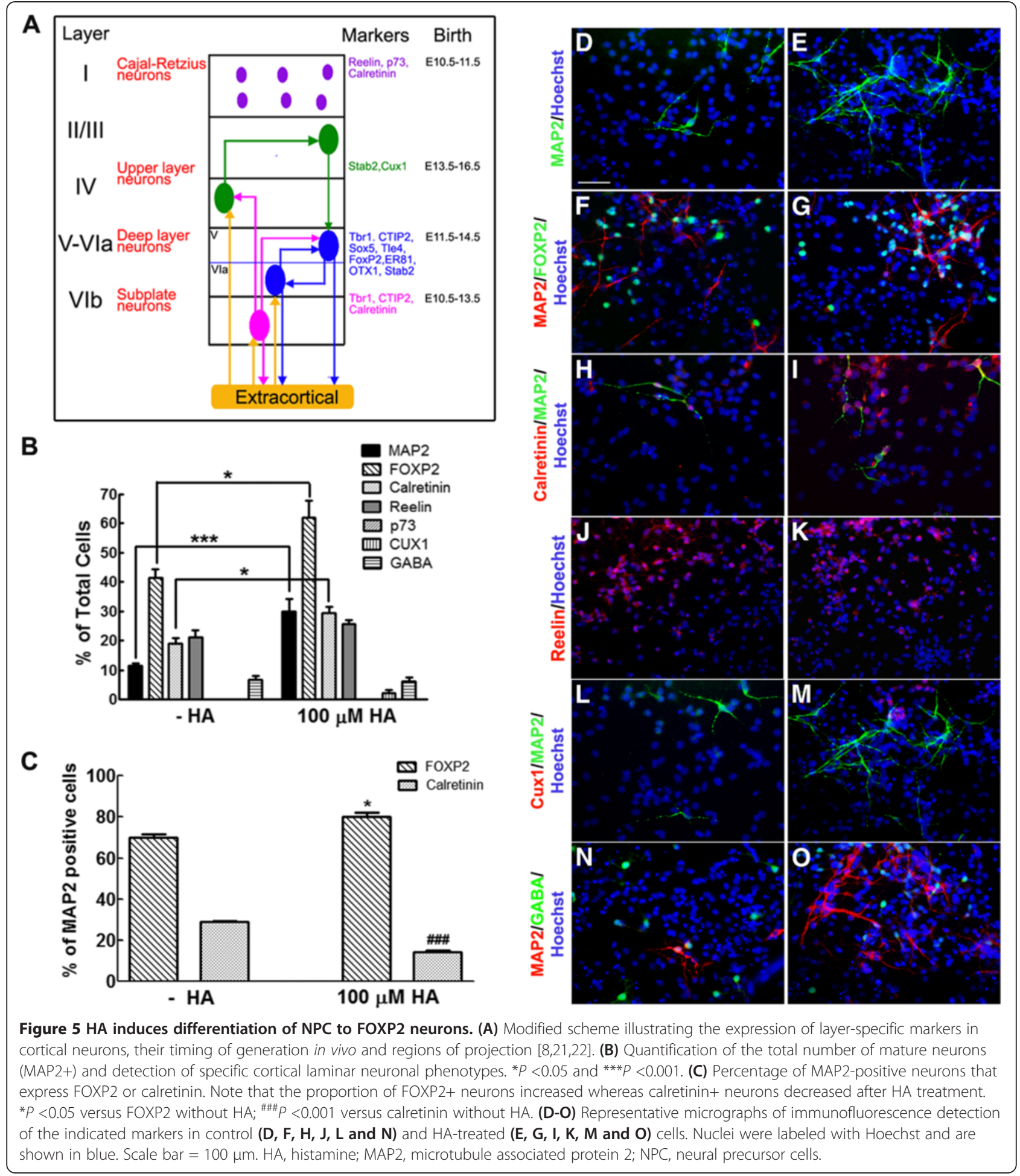

per clone, this parameter was quantified. HA, chlorpheniramine and cimetidine, each added alone, significantly decreased cell numbers. The increase caused by HA was sensitive to chlorpheniramine, but not to cimetidine (Figure 1E). Images taken from the center of the colonies (Figures 1A to 1D) show that individual cells have similar sizes, but in the HA+ chlorpheniramine condition, cells were more disperse, suggesting that specific activation of $\mathrm{H}_{2} \mathrm{R}$ might promote migration/motility. On the other hand, $\mathrm{H}_{1} \mathrm{R}$ activation (HA+cimetidine) could be responsible for the compaction of the clonal colony. Further research is needed to elucidate these intriguing effects. 
In clonal conditions, the differentiation potential of NPC shifts from neurogenic to astrocytogenic after several passages, similar to what happens in high-density cultures [23]. We show that HA is able to significantly increase neuronal differentiation, as measured by the proportion of colonies containing mature (MAP2+) neurons. The neuronal-promoting action of $\mathrm{HA}$ was also dependent upon activation of $\mathrm{H}_{1} \mathrm{R}$, since this effect was sensitive to chlorpheniramine, but not to cimetidine. We also analyzed astrocytic differentiation in clonal cultures. Although at higher cell density, HA reduces the proportion of astrocytes [16], we found GFAP+ cells in all clonal colonies, indicating that neither HA nor its antagonists precluded astroglial commitment, and that the differentiation potential of a single NPC is conserved in the presence of HA. Therefore, HA seems to be promoting differentiation with neuronal bias in clonal cultures through activation of $\mathrm{H}_{1} \mathrm{R}$.

Changes in $\left[\mathrm{Ca}^{2+}\right]_{\mathrm{i}}$ play diverse roles in nervous system development including differentiation of neural cells $[24,25]$, chemotaxis $[26,27]$, proliferation [28] and morphology [29]. Although a high proportion of NPC in our cultures expresses $\mathrm{H}_{1} \mathrm{R}(81 \%)$, only $65 \%$ express functional receptors, as shown by the increase in $\left[\mathrm{Ca}^{2+}\right]_{\mathrm{i}}$ promoted by HA. The increase in $\left[\mathrm{Ca}^{2+}\right]_{\mathrm{i}}$ due to HA was completely blocked by chlorpheniramine and significantly reduced in the absence of extracellular $\mathrm{Ca}^{2+}$. Activation of $\mathrm{H}_{1} \mathrm{R}$ leads to the production of $\mathrm{IP}_{3}$ and diacylglycerol, that in turn

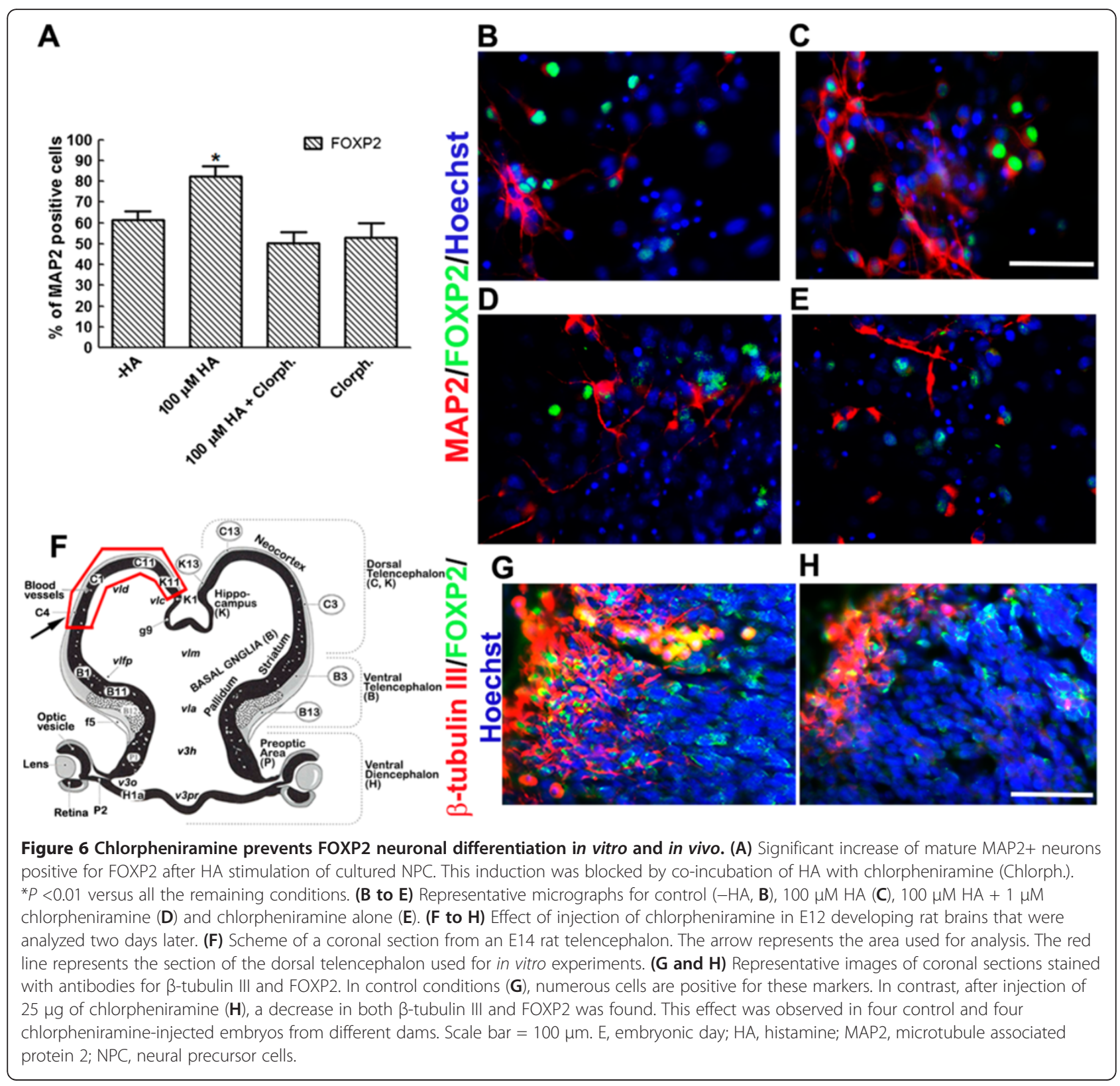


promote an increase in $\left[\mathrm{Ca}^{2+}\right]_{\mathrm{i}}$ due to activation of $\mathrm{IP}_{3}$ receptors in the endoplasmic reticulum, and activation of protein kinase $\mathrm{C}$; our results following $\mathrm{HA}$ addition in the absence of $\mathrm{Ca}^{2+}$ in the extracellular medium strongly suggest that cultured NPC activate this intracellular-mediated $\mathrm{Ca}^{2+}$ increase. Calcium release from intracellular stores into the cytosol is a critical component during ontogenesis $[19,20]$, and this HA-induced $\mathrm{Ca}^{2+}$ rise might contribute to neuronal commitment, with the involvement of several $\mathrm{Ca}^{2+}$-activated protein kinases and transcriptional regulation [30]. HA also increases $\left[\mathrm{Ca}^{2+}\right]_{\mathrm{i}}$ through $\mathrm{H}_{1} \mathrm{R}$ activation in undifferentiated mouse embryonic carcinoma pluripotent cells [18]. Recently, mouse embryonic stem cells were engineered to express a $\mathrm{Ca}^{2+}$-sensitive protein, and $\mathrm{HA}$ was used to select clones that augmented $\left[\mathrm{Ca}^{2+}\right]_{\mathrm{i}}$, confirming the presence of histaminergic G-protein coupled receptors in pluripotent stem cells. Furthermore, neural differentiation of these embryonic stem cells rendered cells that also were able to increase $\left[\mathrm{Ca}^{2+}\right]_{\mathrm{i}}$ after addition of $100 \mu \mathrm{M} H A$; all these effects were mediated by $\mathrm{H}_{1} \mathrm{R}$ [31], which is consistent with our findings.

The response of cells to FGFs during CNS development is mediated by membrane high-affinity FGFRs $[32,33]$. In particular, FGF-2 binds preferentially to FGFR1 and FGFR2, and with less affinity to FGFR3. FGF-2 knockout mice have only half of the neural precursor population when neurogenesis begins, leading to a loss of pyramidal neurons in the anterior cerebral cortex and to a dramatic decrease of glutamatergic cortical neurons in the adult brain [34-36]. In agreement, expression of a dominant negative form of FGFR1 in the dorsal telencephalic and mesencephalic areas from E9.5 onwards, revealed abnormalities in the medial prefrontal cortex and temporal cortical regions. A $30 \%$ to $40 \%$ reduction in cortical thickness which particularly affected the lower cortical layers was reported. This was accompanied by a reduction in cell number and neuronal soma size, shorter dendritic processes, as well as a marked reduction in the number of glutamatergic neurons from layer VI with no effects on GABAergic interneurons [37].

Regulation of FGFRs can participate in both proliferation and commitment of NPC. Our results using RTPCR show that NPC express all FGFR tested, with the exception of FGFR2-IIIB, and that the expression of FGFR1 and FGFR2-IIIC were up-regulated at 30 and 120 minutes by $\mathrm{HA}$ with a transient decrease at $60 \mathrm{mi}-$ nutes. These changes might be explained by $\mathrm{H}_{1} \mathrm{R}$ desensitization, which occurs after 30 minutes and is relieved after 120 minutes in cerebral brain slices from adult rodents [38]. Previous studies demonstrated that FGFR1 mRNA is expressed in the dorsal ventricular zone (VZ), the primordium of the cerebral cortex [39]. FGFR2-IIIC expression is particularly restricted to the
$\mathrm{VZ}$ of the basal forebrain and other ventral structures where proliferation of precursors occurs [40]. FGFR3 and FGFR4 are strongly expressed in the VZ during CNS development, but at later stages, FGFR3 expression appears largely confined to glia $[41,42]$. We propose that $\mathrm{HA}$ stimulation of $\mathrm{H}_{1} \mathrm{R}$ regulates FGFR1 expression and these effects might be related to neuronal differentiation since the transcriptional increases of FGFR1 were sensitive to $\mathrm{H}_{1} \mathrm{R}$ blockade, and FGFR1 mRNA showed the highest increase (550\% relative to control levels) after two hours of HA exposure.

It has been shown that $\left[\mathrm{Ca}^{2+}\right]_{\mathrm{i}}$ and FGFR activation are tightly related. FGF-2, but not epidermal growth factor, causes an increase in $\left[\mathrm{Ca}^{2+}\right]_{\mathrm{i}}$, which later on is correlated with neuronal differentiation in telencephalic neural precursors [43]. In addition, other factors might contribute to HA-induced neurogenesis. Our recent results [17] suggest that the HA neurogenic effect is at the level of cell commitment rather than a terminal differentiation effect: HA present only during differentiation of cortical NPC did not result in increased neuronal differentiation [17]. One of the underlying mechanisms for the neurogenic effect of HA includes increased expression of Prox 1 and Neurogenin1 in the presence of FGF-2, which implies a HA-induced neuronal commitment. Accordingly, results reported recently indicate that HA induces neuronal differentiation from cultured mouse subventricular zone stem/progenitor cells by $\mathrm{H}_{1} \mathrm{R}$ activation, an effect that involves increased expression of Mash1, Dlx2 and Neurogenin1 [44]. Regarding differentiation of neurons in the cerebral cortex, several studies have implicated the participation of FGFR1 [37] and Prox1 in neuron commitment and differentiation $[45,46]$.

We found that HA, in addition to enhancing neuronal differentiation monitored through MAP2 expression, is also able to increase significantly the proportion of the neuronal population expressing the deep layer marker FOXP2 in cultured NPC. Calretinin, a marker that in principle is augmented after HA treatment when we analyzed the total number of cells, actually decreased when we calculated the proportion of calretinin+/MAP2+ cells before and after HA (Figure $5 \mathrm{C}$ ). Thus, HA specifically caused increased numbers of FOXP2+ neurons. This induction was completely abolished by chlorpheniramine, identifying $\mathrm{H}_{1} \mathrm{R}$ as responsible for this effect.

The main source of cortical neurons is the neuroepithelium of the VZ, where precise timing generates first the deep layer (IV to VI) neurons (E11.5 to E14.5), followed by more superficial neurons (layers II/III), starting at E13.5 and ending at E16.5 (Figure 5A) [8,47]. HA concentration in the prosencephalon appears at E12 and peaks at E14 to E16 [9], suggesting a role of this biogenic amine on timing generation of specific types of neurons. Messenger RNA for histaminergic receptors 
are expressed at these stages of development as evidenced by in situ hybridization [48-50]. In particular, the cerebral cortex expresses $\mathrm{H}_{1} \mathrm{R}$ during development [48]. Intrauterine injection of chlorpheniramine in the lateral ventricles in E12 rat embryos precluded the expression of both $\beta$-tubulin III and FOXP2, suggesting a role of $\mathrm{H}_{1} \mathrm{R}$ during cerebral cortical development.

\section{Conclusions}

In the present study we demonstrate that the neurogenic effect of $\mathrm{HA}$ by stimulation of $\mathrm{H}_{1} \mathrm{R}$ is present in clonal density cultures; we also show that $\mathrm{H}_{1} \mathrm{R}$-induced neuronal differentiation correlates with an increase in $\left[\mathrm{Ca}^{2+}\right]_{\mathrm{i}}$ and the up-regulation of FGFR1. Interestingly, we found that $100 \mu \mathrm{M}$ HA promotes differentiation of cerebrocortical NPC into FOXP2 neurons; in agreement, $\mathrm{H}_{1} \mathrm{R}$ antagonism in vivo interferes with $\beta$-tubulin III and FOXP2 immunoreactivity in the developing cerebral cortex.

\section{Methods}

\section{Cell culture}

Animal procedures were approved by the local Animal Care and Use Committee and complied with local (NOM062-ZOO-1999) and international guidelines (Animal Welfare Assurance A5281-01). In order to obtain multipotent NPC [51], E14 embryos were extracted from pregnant Wistar rats and cerebral cortices were dissected in Krebs solution $\left(100 \mathrm{mM} \mathrm{NaCl}, 2 \mathrm{mM} \mathrm{KCl}, 0.6 \mathrm{mM} \mathrm{KH_{2 }} \mathrm{PO}_{4}, 12\right.$ $\mathrm{mM} \mathrm{NaHCO}, 2.2 \mathrm{mM} \mathrm{MgSO}_{4}, 7 \mathrm{mM}$ glucose, $0.1 \%$ phenol red and $0.3 \%$ bovine serum albumin). The tissue was mechanically dissociated to a single cell suspension. Cells were recovered by centrifugation, re-suspended and cultured on plasticware previously treated with $15 \mu \mathrm{g} / \mathrm{mL}$ poly-L-ornithine (Sigma, St. Louis, MO, USA) and $1 \mu \mathrm{g} / \mathrm{ml}$ human fibronectin (Invitrogen, Carlsbad, CA, USA) in fully defined $\mathrm{N} 2$ medium containing $10 \mathrm{ng} / \mathrm{ml}$ FGF-2 (Peprotech, Rocky Hill, NJ, USA) as mitogen. Passage (P) of cells was made with $0.1 \mathrm{mM}$ ethylenediaminetetraacetic acid (EDTA) in PBS. P2 cells were maintained during eight (clonal) or four (high density) days in proliferative control (N2 medium $+10 \mathrm{ng} / \mathrm{ml}$ FGF-2) and experimental (N2 medium $+10 \mathrm{ng} / \mathrm{mL}$ FGF- $2+100 \mu \mathrm{M} \mathrm{HA}$ alone and/or HR antagonist) conditions. Cells were seeded at low $(1 \mathrm{x}$ $10^{3}$ cells in 6-cm plates; clonal experiments), standard ( $1 \mathrm{x}$ $10^{4}$ cells in 24-well plates for phenotype analysis) or high density ( $3 \times 10^{4}$ in 6-well plates for mRNA expression analysis). Differentiation was promoted by removing FGF2 and keeping the cells for six days in N2 medium +200 $\mu \mathrm{M}$ ascorbic acid in the presence or absence of HA and/ or HR antagonists. In both high-density and clonal experiments, HA and/or HR antagonists were present during both proliferation and differentiation stages.

$\mathrm{HA} \mathrm{H}_{1} \mathrm{R}$ and $\mathrm{H}_{2} \mathrm{R}$ antagonists were used, in combination with $100 \mu \mathrm{M} \mathrm{HA}$, to establish if such receptors were responsible for HA effects in clonal cultures, and to establish the participation of these histaminergic receptors on cell differentiation phenotypes. Chlorpheniramine (Sigma) was used as a $\mathrm{H}_{1} \mathrm{R}$ antagonist at $1 \mu \mathrm{M}$ and as a $\mathrm{H}_{2} \mathrm{R}$ antagonist we used cimetidine at $30 \mu \mathrm{M}$ (Sigma). $\mathrm{H}_{1} \mathrm{R}$ and/or $\mathrm{H}_{2} \mathrm{R}$ antagonists were added to control and $100 \mu \mathrm{M}$ HA-treated cells during proliferation and differentiation phases. We also studied the effects of these antagonists on FGFRs expression at the end of proliferation phase.

For clonal analysis, reported procedures were followed [51]. In brief, P2 dissociated cells plated at 1,000 cells/6$\mathrm{cm}$ dish were allowed to attach for three hours. Afterwards, 15 to 20 well-isolated cells were identified by a marking objective (Nikon, Tokyo, Japan) with a $1.8 \mathrm{~mm}$ circle. Only clones arising from single cells were analyzed. To make sure there was no contribution of migrating cells to the colony, the marked areas were monitored on a daily basis to detect cells coming close to the borders of the circle. A total of 5 to 7 clones in duplicate (10 to 14 colonies per experiment, $\mathrm{n}=4$ to 5 ) were analyzed.

\section{Immunocytochemistry and immunohistochemistry}

Previously reported standard procedures were used [16,52]. Differentiated P2 cortical cells or tissue slices were fixed with $4 \%$ paraformaldehyde in PBS, pH 7.4 for 20 minutes at $4{ }^{\circ} \mathrm{C}$, permeabilized and blocked for 1 hour with $0.3 \%$ triton $\mathrm{X}-100$ and $10 \%$ normal goat serum (NGS) in PBS. Samples were incubated overnight at $4^{\circ} \mathrm{C}$ with the following primary antibodies diluted in PBS containing 10\% NGS: rabbit polyclonal anti-GFAP (1:2000, DAKO, Carpinteria, CA, USA); mouse monoclonal antibody anti-MAP2 (1:500, Millipore, Billerica, MA, USA); anti- $\beta$-tubulin III (1:2000, Covance, Princeton, NJ, USA); rabbit polyclonal anti- $\mathrm{H}_{1} \mathrm{R}$ (1:500, Santa Cruz Biotechnology, Dallas, TX, USA); goat polyclonal anti- $\mathrm{H}_{2} \mathrm{R}$ antibody (1:500, Santa Cruz Biotechnology); anti-Forkhead box 2, (FoxP2; 1:1000, Sigma); anti-reelin (1:600, Millipore); antiCut-like homeobox 1 (CUX1; 1:100, Sigma), anti-calretinin (1:1000, Swant, Marly, Switzerland), anti-tumor protein p73 (p73; 1:450, Santa Cruz Biotechnology), and antiGABA (1:1000, Sigma). Alexa-Fluor 488 goat anti-rabbit immunoglobulin G (IgG) and Alexa 568 goat anti-mouse IgG were used as secondary antibodies (1:500; Invitrogen) diluted in PBS/10\% NGS. Nuclei were stained with Hoechst 33258 ( $1 \mathrm{ng} / \mathrm{ml}$; Sigma). Immunostainings were visualized and photographed with an epifluorescence microscope. Negative controls without primary antibodies did not show unspecific staining (data not shown).

\section{Cell counting}

Cell counts from immunocytochemical stainings were performed in pictures taken with a Nikon digital camera 
and the Nikon ACT-1 imaging software. Quantification of cells was performed by counting the number of Hoechst stained nuclei (total cells) and the specified markers in at least eight random fields, from three to four independent experiments made in duplicate.

For clonal experiments, single cells were marked three hours after seeding and let to proliferate for eight days, followed by six days of differentiation. Immunodetection of MAP2 and GFAP was performed. Results are expressed as the percentage of colonies containing MAP2+ neurons, relative to total clonal colonies. In order to estimate the total number of cells in each clone, as well as to measure the area occupied by every colony, cultures were fixed in $10 \%$ formol-PBS, $\mathrm{pH} 7.4$, washed and incubated with a $0.5 \%$ solution of crystal violet for 10 minutes at $21^{\circ} \mathrm{C}$. After thorough washing with bi-distilled water, the number of cells from clonal colonies was counted, and the area of each clonal colony was measured from four to six experiments. For cell counting and area measurement, microphotographs were taken of single clones and merged in composite images with Adobe Photoshop software and analyzed with the aid of ImageJ software.

\section{Intracellular calcium measurements}

To study changes in intracellular calcium $\left(\left[\mathrm{Ca}^{2+}\right]_{\mathrm{i}}\right)$ induced by $100 \mu \mathrm{M}$ HA, undifferentiated NPC were loaded for 40 minutes at $37^{\circ} \mathrm{C}$ in $\mathrm{N} 2$ medium with $5 \mu \mathrm{M}$ Fura-2 AM, which diffuses across the cell membrane and is deesterified by intracellular esterases to yield the ratiometric calcium probe Fura-2. Cells were detached, centrifuged and seeded at $1 \times 10^{5}$ cells per $3.5-\mathrm{cm}$ culture dishes with glass bottom (MatTek Corporation, Ashland, MA, USA), previously treated with $15 \mu \mathrm{g} / \mathrm{ml}$ poly-L-ornithine (Sigma) and $1 \mu \mathrm{g} / \mathrm{ml}$ human fibronectin (Invitrogen) in N2 medium. After 2 hours, attached cells were incubated at $37^{\circ} \mathrm{C}$ in Hank's solution $(137 \mathrm{mM} \mathrm{NaCl}, 5 \mathrm{mM} \mathrm{KCl}, 0.3$ $\mathrm{mM} \mathrm{NaH}{ }_{2} \mathrm{PO}_{4}, 0.8 \mathrm{mM} \mathrm{MgSO}, 1 \mathrm{mM} \mathrm{MgCl}, 5 \mathrm{mM}$ $\mathrm{CaCl}_{2}, 5 \mathrm{mM}$ glucose, $2 \mathrm{mM}$ glutamine, $10 \mathrm{mM}$ Tris- $\mathrm{HCl}$, $\mathrm{pH}$ 7.4) for 10 minutes; after this stabilization time, Hank's solution was substituted by Hank's with $\mathrm{Ca}^{2+}(5 \mathrm{mM})$ or without $\mathrm{Ca}^{2+}$, according to the experimental paradigm. Changes in $\left[\mathrm{Ca}^{2+}\right]_{\mathrm{i}}$ were monitored through ratiometric Fura-2 fluorescent signal after excitation alternating between 340 and $380 \mathrm{~nm}$ and emission set at $510 \mathrm{~nm}$ in a Carl Zeiss Live Cell Imaging system using AxioVision software at $37^{\circ} \mathrm{C}$. Analysis of images was made offline by calculating the emission ratio generated by excitation at $340 \mathrm{~nm}$ divided by that measured at $380 \mathrm{~nm}\left(R=F_{340} / F_{380}\right)$. HR antagonists were added 5 minutes before HA stimulus and were maintained during HA stimulation.

\section{RNA extraction and RT-PCR}

RNA was isolated from non-differentiated cultures using TRIZOL (Invitrogen). In order to have enough RNA,
NPC were seeded at $3 \times 10^{4}$ cells per well in 6-well plates, incubated with FGF-2 for four days, and treated at that point (time zero) with histaminergic compounds. Total RNA was extracted after 30,60 or 120 minutes. RNA $(1 \mu \mathrm{g})$ was reverse-transcribed with random hexamers and 500 to $800 \mathrm{ng}$ from the RT reaction were used for PCR containing $2 \mathrm{U}$ of Taq DNA polymerase (Invitrogen), 20 pmol of specific primers (Sigma; sequences listed below), $500 \mu \mathrm{M}$ deoxynucleoside triphosphates and $1.5 \mathrm{mM} \mathrm{MgCl}_{2}$. Forward (F) and reverse (Rev) primer sequences (all in 5/-3/orientation) used for cDNA amplifications were as follows: FGFR1, F: CAACTggCTgCgggATgggg, Rev: gC gCCACAggCCTACggTTT (266 bp); FGFR2-IIIB, F: gg TCCTgAAgCACTCggggA, Rev: gCTAgCATCggggTgT CCgC (456 bp); FGFR2-IIIC, F: CCTgAAggCCgCCgg TgTTA, Rev: CAgggggATgCgCTTggTCA (340 bp); FGFR3, F: gTgTggTgCCCTCTgACCgC, Rev: CACgCT gCCAgCCTCgTCAA (467 bp); FGFR4, F: CCCggCA TCCCAgTggAggA, Rev: gTTggAgTCCCACggCCACg (392 bp); glyceraldehyde phosphate dehydrogenase (GAPDH), F: ATCACCATCTTCCAggAgCG, Rev: CCTgCTTCACCAC CACCTTCTTg (573 bp).

For FGFR3 and FGFR4, amplification was made as follows: denaturalization at $95^{\circ} \mathrm{C}$ for 15 minutes, 30 cycles of denaturalization at $95^{\circ} \mathrm{C}$ for 1 minute, annealing at $62^{\circ} \mathrm{C}$ for 1 minute, and elongation at $72^{\circ} \mathrm{C}$ for 1 minute; for FGFR1 and FGFR2IIIC: denaturalization at $95^{\circ} \mathrm{C}$ for 15 minutes, 30 cycles of denaturalization at $95^{\circ} \mathrm{C}$ for 1 minute, annealing at $60^{\circ} \mathrm{C}$ for 1 minute, and elongation at $72^{\circ} \mathrm{C}$ for 1 minute; for FGFR2IIIB: denaturalization at $95^{\circ} \mathrm{C}$ for 15 minutes, 30 cycles of denaturalization at $95^{\circ} \mathrm{C}$ for 1 minute, annealing at $64^{\circ} \mathrm{C}$ for 1 minute, and elongation at $72^{\circ} \mathrm{C}$ for 1 minute. Final extension at $74^{\circ} \mathrm{C}$ for 10 minutes was terminated by rapid cooling at $4^{\circ} \mathrm{C}$. Since we were not able to detect any FGFR2-IIIB expression, nested PCR reactions were performed, but we were still unable to see any amplification.

PCR products were analyzed in $2 \%$ agarose gel electrophoresis and the size of the reaction products was determined by comparison with molecular weight standards after ethidium bromide staining. Expression analysis was made by endpoint RT-PCR. Signals from the products obtained from the RT-PCR reactions were quantified by densitometry using ImageJ software (NIH). FGFRs expression was normalized to GAPDH expression assessed from the same cDNA in parallel PCR reactions and loaded in the same gels. The standardized optic density mean of each triplicated PCR was then expressed relative to the levels of GAPDH. As a negative control for PCR amplification, reactions with RNA in the absence of retro-transcription were included. The positive controls consisted of RNA extracted from adult cerebral cortex (FGFR1 and FGFR2-IIIC) or kidney (FGFR2-IIIB, FGFR3 and FGFR4), which were used to synthesize cDNA and amplified by PCR as described above. 
Representative bands of the amplified PCR products were recovered from gels using the Qiaquick gel extraction kit (Qiagen, Germantown, MD, USA) according to the manufacturer's instructions. These bands were sequenced at the Molecular Biology Unit in our Institute, and it was confirmed that all bands correspond indeed to FGFR.

\section{In vivo intrauterine injection of embryos}

To study the effect of the $\mathrm{H}_{1} \mathrm{R}$ antagonist chlorpheniramine on cortical development in vivo, we used an ultrasound (Ultraview MHF-1) imaging device coupled to a microinjection system to introduce $2 \mu$ of injectable water (control) or the same volume containing $25 \mu \mathrm{g}$ of chlorpheniramine into the embryo's telencephalic ventricles at E12 as described [53]. Briefly, the dam was placed in an airtight anesthesia chamber with $3 \%$ sevoflurane (Abbott Laboratories, Abbott Park, IL, USA) in 95\% $\mathrm{O}_{2-}$ $5 \% \mathrm{CO}_{2}$ gas mixture. The rats were maintained with a mask of inhaled anesthesia in $0.5 \%$ to $1.5 \%$ sevoflurane on a heating pad. The skin was shaved and aseptically prepared to make an incision in the abdominal skin and muscle. The uterine horns were exposed and a single embryo was secured to proceed with injection using a glass needle. The lateral ventricles were visualized while making the injections and embryos were identified by their position in the uterine horn. After 48 hours, the dam was euthanized and the E14 embryos were recovered. Only embryos that had a beating heart were selected for further analysis. After fixation with $4 \%$ paraformaldehyde in PBS ( $\mathrm{pH}=7.4$ ) for 24 to 48 hours at $4^{\circ} \mathrm{C}$, embryos were cryoprotected with $30 \%$ sucrose and rapidly frozen using liquid nitrogen. Coronal slices $(20 \mu \mathrm{m})$ were obtained and stained with antibodies that recognize $\beta$-tubulin III or FOXP2.

\section{Statistics}

All data are presented as mean \pm standard error of the mean (S.E.M). One-way analysis of variance (ANOVA) was performed for statistical analysis, multiple comparisons were made using the post-hoc Student-Newman-Keuls test to compare data; for mRNA expression analysis we used the Dunnett test, in order to compare the experimental condition versus its corresponding control. Differences were considered statistically significant at $P<0.05$. Graphs and statistical analysis were performed using GraphPad and GraphPad Instat software respectively.

\section{Additional file}

Additional file 1: Title: Proliferating NPC expresses $H_{1} R$ and $H_{2} R$. Description: Immunodetection of $\mathrm{H}_{1}(\mathrm{~A}$ and $\mathrm{B}), \mathrm{H}_{2}$ (C and D) receptors (red) and nuclei stained with Hoechst (blue). The percentage indicates the proportion of cells expressing each receptor relative to total cells counted from 10 fields in control ( $A$ and $C$ ) and $\mathrm{HA}$-treated ( $B$ and $D$ ) conditions. Note that $100 \mu \mathrm{M} \mathrm{HA}$ ( $B$ and $D$ ) does not modify the proportion of cells expressing histaminergic receptors. Scale bar $=100 \mu \mathrm{m}$.

\section{Abbreviations}

bp: base pair; CNS: central nervous system; E: embryonic day; F: forward; FGFR: fibroblast growth factor receptor; GABA: gamma-amino butyric acid; GADPH: glyceraldehyde phosphate dehydrogenase; GFAP: glial fibrillary acidic protein; $H A$ : histamine; $H_{1} R$ : histamine type 1 receptor; $H_{2} R$ : histamine type 2 receptor; $\mathrm{H}_{3} \mathrm{R}$ : histamine type 3 receptor; $\mathrm{IP}_{3}$ : inositol triphosphate; MAP2: microtubule associated protein 2; NGS: normal goat serum; NPC: neural precursor cells; P: passage; PBS: phosphate-buffered saline; R: ratio; Rev: reverse; RT-PCR: reverse transcriptase-polymerase chain reaction; VZ: ventricular zone.

\section{Competing interests}

The authors declare that they have no competing interests.

\section{Authors' contributions}

AMH participated in all experiments and analyzed data. GRM contributed to clonal experiments and immunocytochemistry. IEA took part in intracellular calcium, RT-PCR measurements and intrauterine injections. IV contributed to experiment design/supervision and obtained funding. All authors participated in the preparation of the manuscript. All authors read and approved the final manuscript.

\section{Acknowledgements}

We thank Emmanuel Díaz-Martínez for technical support. This work was supported by Universidad Nacional Autónoma de México (PAPIIT grants IN224210 and IN208713).

\section{Author details}

'Instituto de Fisiología Celular - Neurociencias, Universidad Nacional Autónoma de México, México, D.F. 04510, México. ${ }^{2}$ Departamento de Biología Celular, Instituto Nacional de Perinatología "Isidro Espinosa de los Reyes", Montes Urales 800, Colonia Lomas de Virreyes, C.P. 11000, México, D. F., México.

Received: 12 September 2012 Accepted: 29 January 2013 Published: 7 March 2013

\section{References}

1. Rakic P, Caviness VS Jr: Cortical development: view from neurological mutants two decades later. Neuron 1995, 14:1101-1104.

2. Olson EC, Walsh CA: Smooth, rough and upside-down neocortical development. Curr Opin Genet Dev 2002, 12:320-327.

3. Ayala R, Shu T, Tsai LH: Trekking across the brain: the journey of neuronal migration. Cell 2007, 128:29-43.

4. Costa MR, Hedin-Pereira C: Does cell lineage in the developing cerebral cortex contribute to its columnar organization? Front Neuroanat 2010, 4:26.

5. Meyer G: Building a human cortex: the evolutionary differentiation of Cajal-Retzius cells and the cortical hem. J Anat 2010, 217:334-343.

6. Thomson AM, Lamy C: Functional maps of neocortical local circuitry. Front Neurosci 2007, 1:19-42.

7. Shen $Q$, Wang Y, Dimos JT, Fasano CA, Phoenix TN, Lemischka IR, Ivanova NB, Stifani S, Morrisey EE, Temple S: The timing of cortical neurogenesis is encoded within lineages of individual progenitor cells. Nat Neurosci 2006, 9:743-751.

8. Gaspard N, Bouschet T, Hourez R, Dimidschstein J, Naeije G, van den Ameele J, Espuny-Camacho I, Herpoel A, Passante L, Schiffmann SN, Gaillard A, Vanderhaeghen P: An intrinsic mechanism of corticogenesis from embryonic stem cells. Nature 2008, 455:351-357.

9. Vanhala A, Yamatodani A, Panula P: Distribution of histamine-, 5-hydroxytryptamine-, and tyrosine hydroxylase-immunoreactive neurons and nerve fibers in developing rat brain. J Comp Neurol 1994, 347:101-114.

10. Specht LA, Pickel VM, Joh TH, Reis DJ: Light-microscopic immunocytochemical localization of tyrosine hydroxylase in prenatal rat brain. II. Late ontogeny. J Comp Neurol 1981, 199:255-276.

11. Lidov HG, Molliver ME: Immunohistochemical study of the development of serotonergic neurons in the rat CNS. Brain Res Bull 1982, 9:559-604. 
12. Auvinen S, Panula P: Development of histamine-immunoreactive neurons in the rat brain. J Comp Neurol 1988, 276:289-303.

13. Reiner PB, Semba K, Fibiger HC, McGeer EG: Ontogeny of histidinedecarboxylase-immunoreactive neurons in the tuberomammillary nucleus of the rat hypothalamus: time of origin and development of transmitter phenotype. J Comp Neurol 1988, 276:304-311.

14. Sauvageot CM, Stiles CD: Molecular mechanisms controlling cortical gliogenesis. Curr Opin Neurobiol 2002, 12:244-249.

15. Molina-Hernandez A, Diaz NF, Arias-Montano JA: Histamine in brain development. J Neurochem 2012, 122:872-882.

16. Molina-Hernandez A, Velasco I: Histamine induces neural stem cell proliferation and neuronal differentiation by activation of distinct histamine receptors. J Neurochem 2008, 106:706-717.

17. Rodriguez-Martinez G, Velasco I, Garcia-Lopez G, Solis KH, Flores-Herrera H, Diaz NF, Molina-Hernandez A: Histamine is required during neural stem cell proliferation to increase neuron differentiation. Neuroscience 2012, 216:10-17.

18. Bloemers SM, Leurs R, Smit MJ, Verheule S, Tertoolen LG, Timmerman H, de Laat SW: Mouse P19 embryonal carcinoma cells express functional histamine H1-receptors. Biochem Biophys Res Commun 1993, 191:118-125.

19. Lohmann C, Myhr KL, Wong RO: Transmitter-evoked local calcium release stabilizes developing dendrites. Nature 2002, 418:177-181.

20. Lohmann C, Wong RO: Regulation of dendritic growth and plasticity by local and global calcium dynamics. Cell Calcium 2005, 37:403-409.

21. Gaspard N, Gaillard A, Vanderhaeghen P: Making cortex in a dish: in vitro corticopoiesis from embryonic stem cells. Cell Cycle 2009, 8:2491-2496.

22. Sansom SN, Livesey FJ: Gradients in the brain: the control of the development of form and function in the cerebral cortex. Cold Spring Harb Perspect Biol 2009, 1:a002519.

23. Chang MY, Park CH, Lee SY, Lee SH: Properties of cortical precursor cells cultured long term are similar to those of precursors at later developmental stages. Brain Res Dev Brain Res 2004, 153:89-96.

24. Gu X, Spitzer NC: Distinct aspects of neuronal differentiation encoded by frequency of spontaneous Ca2+ transients. Nature 1995, 375:784-787.

25. Spitzer NC, Root CM, Borodinsky LN: Orchestrating neuronal differentiation: patterns of $\mathrm{Ca} 2+$ spikes specify transmitter choice. Trends Neurosci 2004, 27:415-421.

26. Kumada $\mathrm{T}$, Komuro $\mathrm{H}$ : Completion of neuronal migration regulated by loss of $\mathrm{Ca}(2+)$ transients. Proc Natl Acad Sci U S A 2004, 101:8479-8484.

27. Komuro H, Kumada T: Ca2+ transients control CNS neuronal migration. Cell Calcium 2005, 37:387-393.

28. Lory P, Bidaud I, Chemin J: T-type calcium channels in differentiation and proliferation. Cell Calcium 2006, 40:135-146.

29. Aizawa H, Hu SC, Bobb K, Balakrishnan K, Ince G, Gurevich I, Cowan M, Ghosh A: Dendrite development regulated by CREST, a calciumregulated transcriptional activator. Science 2004, 303:197-202.

30. Leclerc C, Neant I, Moreau M: The calcium: an early signal that initiates the formation of the nervous system during embryogenesis. Front $\mathrm{Mol}$ Neurosci 2012, 5:3.

31. Cainarca S, Fenu S, Ferri C, Nucci C, Arioli P, Menegon A, Piemonti L, Lohmer S, Wrabetz L, Corazza S: A photoprotein in mouse embryonic stem cells measures Ca2+ mobilization in cells and in animals. PLoS One 2010, 5:e8882

32. Szebenyi G, Fallon JF: Fibroblast growth factors as multifunctional signaling factors. Int Rev Cytol 1999, 185:45-106.

33. Iwata T, Hevner RF: Fibroblast growth factor signaling in development of the cerebral cortex. Dev Growth Differ 2009, 51:299-323.

34. Vaccarino FM, Schwartz ML, Raballo R, Nilsen J, Rhee J, Zhou M, Doetschman T, Coffin JD, Wyland JJ, Hung YT: Changes in cerebral cortex size are governed by fibroblast growth factor during embryogenesis. Nat Neurosci 1999, 2:246-253.

35. Raballo R, Rhee J, Lyn-Cook R, Leckman JF, Schwartz ML, Vaccarino FM: Basic fibroblast growth factor (Fgf2) is necessary for cell proliferation and neurogenesis in the developing cerebral cortex. J Neurosci 2000, 20:5012-5023.

36. Korada S, Zheng W, Basilico C, Schwartz ML, Vaccarino FM: Fibroblast growth factor 2 is necessary for the growth of glutamate projection neurons in the anterior neocortex. J Neurosci 2002, 22:863-875.

37. Shin DM, Korada S, Raballo R, Shashikant CS, Simeone A, Taylor JR, Vaccarino F: Loss of glutamatergic pyramidal neurons in frontal and temporal cortex resulting from attenuation of FGFR1 signaling is associated with spontaneous hyperactivity in mice. J Neurosci 2004, 24:2247-2258

38. Bristow DR, Banford PC, Bajusz I, Vedat A, Young JM: Desensitization of histamine $\mathrm{H} 1$ receptor-mediated inositol phosphate accumulation in guinea pig cerebral cortex slices. Br J Pharmacol 1993, 110:269-274.

39. Vaccarino FM, Schwartz ML, Raballo R, Rhee J, Lyn-Cook R: Fibroblast growth factor signaling regulates growth and morphogenesis at multiple steps during brain development. Curr Top Dev Biol 1999, 46:179-200

40. Ragsdale CW, Grove EA: Patterning the mammalian cerebral cortex. Curr Opin Neurobiol 2001, 11:50-58.

41. Ford-Perriss M, Abud H, Murphy M: Fibroblast growth factors in the developing central nervous system. Clin Exp Pharmacol Physiol 2001, 28:493-503.

42. Peters K, Ornitz D, Werner S, Williams L: Unique expression pattern of the FGF receptor 3 gene during mouse organogenesis. Dev Biol 1993, 155:423-430.

43. Maric D, Maric I, Chang YH, Barker JL: Prospective cell sorting of embryonic rat neural stem cells and neuronal and glial progenitors reveals selective effects of basic fibroblast growth factor and epidermal growth factor on self-renewal and differentiation. J Neurosci 2003, 23:240-251.

44. Bernardino L, Eiriz MF, Santos T, Xapelli S, Grade S, Rosa Al, Cortes L, Ferreira R, Braganca J, Agasse F, Ferreira L, Malva JO: Histamine stimulates neurogenesis in the rodent subventricular zone. Stem Cells 2012, 30:773-784.

45. Lavado A, Lagutin OV, Chow LM, Baker SJ, Oliver G: Prox1 is required for granule cell maturation and intermediate progenitor maintenance during brain neurogenesis. PLOS Biol 2010, 8:e1000460.

46. Misra K, Gui H, Matise MP: Prox1 regulates a transitory state for interneuron neurogenesis in the spinal cord. Dev Dyn 2008, 237:393-402.

47. Hevner RF, Daza RA, Rubenstein JL, Stunnenberg H, Olavarria JF, Englund C: Beyond laminar fate: toward a molecular classification of cortical projection/pyramidal neurons. Dev Neurosci 2003, 25:139-151.

48. Kinnunen $A$, Lintunen $M$, Karlstedt $K$, Fukui $H$, Panula $P$ : In situ detection of $\mathrm{H} 1$-receptor mRNA and absence of apoptosis in the transient histamine system of the embryonic rat brain. J Comp Neurol 1998, 394:127-137.

49. Heron A, Rouleau A, Cochois V, Pillot C, Schwartz JC, Arrang JM: Expression analysis of the histamine $\mathrm{H}(3)$ receptor in developing rat tissues. Mech Dev 2001, 105:167-173.

50. Karlstedt K, Senkas A, Ahman M, Panula P: Regional expression of the histamine $\mathrm{H}(2)$ receptor in adult and developing rat brain. Neuroscience 2001, 102:201-208.

51. Johe KK, Hazel TG, Muller T, Dugich-Djordjevic MM, McKay RD: Single factors direct the differentiation of stem cells from the fetal and adult central nervous system. Genes Dev 1996, 10:3129-3140.

52. Diaz NF, Guerra-Arraiza C, Diaz-Martinez NE, Salazar P, Molina-Hernandez A Camacho-Arroyo I, Velasco I: Changes in the content of estrogen alpha and progesterone receptors during differentiation of mouse embryonic stem cells to dopamine neurons. Brain Res Bull 2007, 73:75-80.

53. Garcia-Moreno F, Pedraza M, Di Giovannantonio LG, Di Salvio M, LopezMascaraque L, Simeone A, De Carlos JA: A neuronal migratory pathway crossing from diencephalon to telencephalon populates amygdala nuclei. Nat Neurosci 2010, 13:680-689.

doi:10.1186/1749-8104-8-4

Cite this article as: Molina-Hernández et al:: Histamine up-regulates fibroblast growth factor receptor 1 and increases FOXP2 neurons in cultured neural precursors by histamine type 1 receptor activation: conceivable role of histamine in neurogenesis during cortical development in vivo. Neural Development 2013 8:4. 